\title{
Other Imaging Modalities
}

National Cancer Institute

\section{Source}

National Cancer Institute. Other Imaging Modalities. NCI Thesaurus. Code C19343.

Imaging methods not listed. 